\title{
PENERAPAN PRINSIP 5R (REDUCE, REUSE, RECYCLE, REPLANT DAN REPLACE) SEBAGAI UPAYA EFEKTIF MENANGANI MASALAH SAMPAH RUMAHTANGGA
}

\section{THE APPLICATION OF 5R (REDUCE, REUSE, RECYCLE, REPLANT AND REPLACE) PRINCIPLES TO HANDLE THE HOUSEHOLD WASTE}

\author{
Oleh \\ Nyayu Neti Arianti ${ }^{1)}$, Ellys Yuliarti ${ }^{1)}$, dan Marlin ${ }^{2)}$ \\ 1) Jurusan Sosial Ekonomi Pertanian Fakultas Pertanian UNIB \\ ${ }^{2)}$ Jurusan Agroekoteknologi Fakultas Pertanian UNIB \\ Email: nyayunetiarianti@yahoo.co.id
}

\begin{abstract}
The aims of this activity are 1) to introduce and to apply the $5 R$ principles to handle the household waste, 2) to introduce and to apply composting method of the organic household waste in Takakura Bin, 3) to introduce and to apply the producing method of recycled paper, and 4) to evaluate the technology which introduced and applied. The participants are 11 housewives. The activity methods are extention and practicing (learning by doing). All of participants are exited. The results of evaluation analysis show that 78,41 \% said that the technology which introduced and applied are very good and $21,59 \%$ participants said that the technology are good.
\end{abstract}

Keywords: household waste, 5R principles, takakura bin, recycled paper

\section{PENDAHULUAN}

Hampir semua aktifitas manusia menghasilkan sampah. Mulai dari kegiatan di rumah, kantor, pasar, dan lain-lain. Sampah menjadi permasalahan umum yang semakin menyita perhatian, pikiran dan tenaga. Jika tidak dikelola dengan baik, memang sampah menjadi masalah. Akibat yang ditimbulkan sangat besar, mulai dari masalah kebersihan, kesehatan, merusak pemandangan, sampai kerusakan lingkungan. Namun sebenarnya tidak semua sampah tidak berguna dan menjadi masalah. Jika dikelola dengan baik, ada beberapa jenis sampah yang bisa dimanfaatkan bahkan bernilai ekonomi. Untuk itu perlu upaya untuk memahami bagaimana cara mengelola sampah terutama sampah rumahtangga, karena rumahtangga adalah penghasil sampah terbesar.

Apriadji (2000) mendefinisikan sampah sebagai bahan padat sisa proses industri atau hasil sampingan dari kegiatan rumahtangga. Rumahtangga dengan jumlah anggota sebanyak empat orang rata-rata menghasilkan sampah sebanyak $10 \mathrm{~kg}$ per hari. Di 
Indonesia sekitar 6.500 ton sampah dibuang setiap hari. Sekitar 20 persen sampah mengalir ke sungai atau ke laut dan sisanya dibawa ke TPA (Tempat Pembuangan Akhir) (megapolitan.kompas.com, 2012 dalam Hidayat, 2012).

Sebenarnya masalah sampah bisa ditangani dengan lebih baik jika pada skala rumahtangga sampah dikelola dengan bijak. Namun sayangnya upaya-upaya penanganan sampah pada tingkat rumahtangga belum tersosialisasikan dengan baik. Untuk itu perlu upaya pengenalan prinsip-prinsip pengelolaan sampah serta pengetahuan dan keterampilan pemanfaatan sampah.

Mendaur ulang sampah organik rumahtangga dan sampah kertas dapat menjadi kegiatan yang sangat positif. Selain bermanfaat untuk mengurangi dampak negatif yang ditimbulkan, melalui upaya-upaya tersebut juga dapat dihasilkan barang-barang yang bermanfaat serta bernilai ekonomi.

Adapun permasalahan yang dihadapi oleh khalayak sasaran yang diharapkan dapat ditanggulangi melalui kegiatan ini adalah: 1) Sampah rumahtangga semakin meningkat volumenya dengan semakin meningkatnya jumlah penduduk beserta aktivitasnya, 2) Sampah rumahtangga umumnya tidak dikelola dengan baik, tidak dipilah-pilah menurut jenisnya sehingga sulit diolah lebih lanjut, dan 3) Sampah organik berupa sampah dapur dan sampah anorganik, misalnya sampah kertas, belum dikelola apalagi didaur ulang menjadi barang yang berguna.

Menurut Anwar (2012) sampah terbagi dua macam, yaitu sampah organik dan sampah anorganik. Selanjutnya akan dijelaskan sebagai berikut:

a. Sampah organik

Sampah organik adalah merupakan barang yang dianggap sudah tidak terpakai dan dibuang oleh pemilik/pemakai sebelumnya, tetapi masih bisa dipakai kalau dikelola dengan prosedur yang benar.Sampah organik adalah sampah yang bisa mengalami pelapukan (dekomposisi) dan terurai menjadi bahan yang lebih kecil dan tidak berbau (sering disebut dengan kompos).

Sampah organik berasal dari makhluk hidup, baik manusia, hewan, maupun tumbuhan. Sampah organik sendiri dibagi menjadi:

- Sampah organik basah, yaitu sampah mempunyai kandungan air yang cukup tinggi. Contohnya kulit buah dan sisa sayuran.

- Sampah organik kering, adalah bahan organik lain yang kandungan airnya kecil. Contoh sampah organik kering di antaranya kertas, kayu atau ranting pohon, dan dedaunan kering.

Kompos merupakan hasil pelapukan bahan-bahan organik seperti daun-daunan, jerami, alang-alang, sampah, rumput, dan bahan lain yang sejenis yang proses pelapukannya dipercepat oleh bantuan manusia. Sampah pasar khusus seperti pasar sayur mayur, pasar buah, atau pasar ikan, jenisnya relatif seragam, sebagian besar (95\%) berupa sampah organik sehingga lebih mudah ditangani. Sampah yang berasal 
dari pemukiman umumnya sangat beragam, tetapi secara umum minimal $75 \%$ terdiri dari sampah organik dan sisanya anorganik.

b. Sampah anorganik

Sampah anorganik adalah sampah yang terdiri dari bahan-bahan yang sulit terurai secara biologis sehingga penghancurannya membutuhkan waktu yang sangat lama. Sampah anorganik berasal dari sumber daya alam tak terbarui seperti mineral dan minyak bumi, atau dari proses industri. Beberapa dari bahan ini tidak terdapat di alam seperti plastik dan aluminium. Sebagian zat anorganik secara keseluruhan tidak dapat diuraikan oleh alam, sedang sebagian lainnya hanya dapat diuraikan dalam waktu yang sangat lama. Sampah jenis ini pada tingkat rumah tangga, misalnya berupa botol, botol plastik, tas plastik, dan kaleng.

Contoh sampah anorganik adalah: potongan-potongan/pelat-pelat dari logam, berbagai jenis batu-batuan, pecahan-pecahan gelas, tulang-belulang, kaleng bekas, botol bekas, plastik, kertas dan lain-lain. Sampah anorganik yang paling banyak adalah sampah plastik, karena plastik hampir kegiatan rumahtangga menggunakan bahanbahan atau barang-barang plastik atau berhubungan dengan plastik, misalnya kemasan.

Sampah dapat ditangani dengan berbagai cara: 1) Dipilah, yaitu memisahkan antara sampah yang mudah membusuk (organik) dan sampah yang tidak mudah atau sulit membusuk (anorganik), 2) Dibuat kompos: setelah dipilah, sampah yang mudah busuk seperti bekas makanan dan sayur-sayuran dapat diolah menjadi pupuk kompos, dan 3) Didaur ulang: adapun sampah yang tidak mudah membusuk, seperti plastik atau kertas, dapat diolah menjadi barang yang dapat digunakan kembali atau dijual.

Pengelolaan sampah dimulai dengan memilah-milah sampah. Kegiatan pemilahan sampah dilakukan di tingkat rumahtangga. Sampah dipilah-pilah menurut jenisnya. Pemilahan ini penting agar sampah dapat ditangani lebih lanjut. Manfaat yang didapatkan adalah lingkungan yang bersih dan sehat, bahkan manfaat ekonomi dari pengolahan sampah lebih lanjut. Sampah organik dapat diubah menjadi kompos dan sampah plastik dapat dijadikan barang-barang kerajinan.

Masalah sampah adalah masalah yang rumit. Memberantas sampah bukan cara yang mudah, perlu kemauan dan ketekunan yang tinggi. Memang banyak upaya yang dapat dilakukan untuk memusnahkan sampah, tetapi upaya mengurangi volume sampah itu sendiri merupakan upaya yang paling mendasar. Jika jumlah atau volume sampah berkurang maka tidak perlu dilakukan lebih banyak upaya untuk mengelolanya agar tidak berdampak negatif bagi lingkungan (Sutidja, 1999).

Selama ini dikenal "Prinsip 4 R" untuk mengurangi volume sampah terutama yang dapat diterapkan pada rumahtangga-rumahtangga. Dengan semakin bertambahnya jumlah penduduk maka masalah sampah yang tidak dikelola dengan baik menjadi hal yang sangat penting diperhatikan.

Sementara Safitri ( 2014) memperkenalkan prinsip 4R yang berbeda dimana $R$ yang ke-empat adalah Replace (bukan Replant) yaitu mengganti barang-barang yang berpotensi menciptakan sampah dengan barang lain. Misalnya mengganti kantong "kresek" untuk 
berbelanja ke pasar dengan tas jinjing yang tahan lama, mengganti bungkus plastik dengan bungkus yang berbahan lain yang ramah lingkungan.

Jadi jika digabungkan prinsip-prinsip pengelolaan atau penanganan sampah tersebut, maka menjadi Prinsip 5R, yaitu:

a. Reduce (mengurangi atau menghemat pemakaian barang), misalnya dengan cara membawa kantong plastik sendiri dari rumah ketika akan berbelanja sehingga ketika pulang tidak menambah volume sampah.

b. Reuse (menggunakan atau memakai kembali), memanfaatkan barang-barang yang dianggap sudah tidak berguna, misalnya memanfaatkan gelas plastik bekas air mineral untuk pot tanaman, bekas kemasan minyak goreng atau pewangi pakaian untuk bahan dasar pembuatan payung, dll.

c. Recycle (mendaur ulang), misalnya mendaur ulang kertas, mengolah sampah menjadi pupuk organik atau kompos, dll.

d. Replant (menanam kembali), memanfaatkan sisa bahan pangan terutama sayuran yang bisa ditanam untuk keperluan sehari-hari sehingga dapat menghemat pengeluaran, menanam tanaman langka, tanaman obat, dll.

e. Replace (mengganti), mengganti barang yang berpotensi menjadi sampah terutama sampah anorganik dengan barang lain.

Dengan menerapkan prinsip-prinsip tersebut maka diharapkan jumlah sampah akan berkurang sehingga dapat mengurangi beban lingkungan, kebersihan akan terjaga yang kemudian berdampak kepada kesehatan masyarakat umum. Prinsip ini juga menawarkan alternatif lain upaya pemanfaatan sampah agar menjadi berguna bahkan memberikan nilai tambah ekonomi untuk meningkatkan pendapatan.

Keranjang Takakura adalah hasil temuan Pusdakota Ubaya bersama Pemerintah Kota Surabaya, Kitakyusu International Techno-cooperative Association dan Pemerintah Kitakyusu Jepang pada tahun 2005. Keranjang ini adalah hasil penelitian seorang ahli yang bernama Koji Takakura yang berasal dari Jepang (Anonim ${ }^{1}$, 2008). Anonim ${ }^{2}$ (2011) menjelaskan bahwa keranjang Takakura dirancang untuk mengolah sampah organik rumahtangga. Sumbangsih Mr. Koji Takakura terhadap upaya pengelolaan sampah berbasis masyarakat di Surabaya sangatlah besar. Keberhasilannya malah diapresiasi oleh suatu lembaga internasional yaitu Institute for Global Environment and Strategy (IGES). Pada bulan Februari 2007 IGES mensponsori studi banding 10 kota dari 10 negara untuk melihat pengelolaan sampah berbasis masyarakat di Surabaya. Kota-kota tersebut ingin mencontoh sistem pengomposan yang dikembangkan di Surabaya dengan bantuan Takakura Composting System.

Keranjang Takakura berfungsi sebagai dekomposer, mengubah sampah organik rumahtangga menjadi pupuk kompos siap pakai. Keranjang kompos Takakura atau disebut juga Takakura Home Method terdiri dari sebuah keranjang plastik yang berlubang atau berventilasi, kardus bekas, starter kompos, bantalan sekam dan selembar kain (Anonim ${ }^{3}$, 2012). Keranjang plastik berventilasi bertujuan untuk melancarkan sirkulasi udara di 
dalam keranjang, bandalan sekam berfungsi untuk penampung air lindi dari sampah dan bisa menyerap bau. Bantal sekam ini juga dapat berfungsi sebagai pengontrol udara di temtap pengomposan agar bakteri dapat berkembang dengan baik, sedang kain berfungsi untuk penghalang lalat atau nyamuk atau serangga lain agar tidak masuk ke dalam keranjang.

Jenis sampah yang dapat didekomposisi dalam keranjang Takakura ini misalnya sisa sayuran, sisa nasi, sisa ayam, ikan, kulit telur, sisa lauk pauk, dan kulit buah yang lunak. Kulit buah yang keras seperti kulit salak tidak dapat didekomposisi dalam keranjang ini. Proses pengomposan berlangsung 2-3 bulan. Setelah 3 bulan maka sepertiga bagian bawah isi keranjang dapat diambil dan dapat dipakai sebagai pupuk kompos (Anonim ${ }^{4}, 2013$ ).

Fakta-fakta tentang pentingnya mendaur ulang limbah atau sampah kertas dijelaskan dalam http://greenworld-future.blogspot.com (2011). Fakta-fakta tersebut adalah: a) Proses daur ulang kertas akan mengurangi $73 \%$ pencemaran udara apabila dibandingkan dengan pembuatan kertas dari bahan mentah, b) Sebanyak 12,5 juta ton kertas digunakan setiap tahun di Inggris, c) Dibutuhkan 24 batang pohon untuk membuat 1 ton kertas. Kalau begitu dibutuhkan kira-kira 300 juta batang pohon untuk mencukupi kebutuhan kertas di Inggris saja tiap tahunnya.

Menurut penelitian, ternyata kertas daur ulang menghemat sumber daya alam, menghemat energi, mengurangi emisi gas rumah kaca, dan membuat ruang TPA gratis untuk jenis lain dari sampah yang tidak dapat didaur ulang. Daur ulang satu ton kertas dapat menghemat 17 pohon, 7.000 galon air, 380 galon minyak, 3,3 meter kubik ruang TPA dan 4.000 kilowatt energi yang cukup untuk kekuatan rumah rata-rata US selama enam bulan dan mengurangi emisi gas rumah kaca oleh satu metrik ton ekuivalen karbon (MTCE).

Pembuatan kertas dari bahan mentah membutuhkan biaya yang sangat besar. Bahan dasarnya berupa pohon menjadikan industri pembuatan kertas menyumbang pemasalahan terbesar bagi pemanasan global. Untuk itu perlu upaya untuk menghemat pemakaian kertas dan mendaur ulang kertas bekas agar dapat dimanfaatkan kembali. Ternyata membuat kertas daur ulang ini tidaklah sesulit yang kita bayangkan. Alat dan bahannya bisa diperoleh dengan mudah dari lingkungan di sekitar kita.

Berdasarkan analisis situasi dan permasalahan tersebut maka kegiatan ini dilakukan dengan tujuan untuk: 1) Mengenalterapkan Prinsip 5R untuk mengatasi masalah sampah rumahtangga, 2) Mengenalterapkan pengolahan sampah organik rumahtangga menjadi kompos dengan Keranjang Takakura, 3) Mengenalterapkan pemanfaatan sampah kertas menjadi kertas daur ulang, dan 4) Mengevaluasi teknologi yang dikenalterapkan.

\section{METODE PENGABDIAN}

Kegiatan ini dilakukan di Kelurahan Kandang Limun Kecamatan Muara Bangkahulu. Kelurahan ini memiliki jumlah penduduk sebanyak 6.370 jiwa dengan 1.401 Kepala Keluarga (KK). Jumlah rumahtangga sebanyak 1.116 unit. Jika satu rumah rata- 
rata menghasilkan $10 \mathrm{~kg}$ per hari, maka jumlah sampah di kelurahan ini mencapai lebih dari 10 ton per hari. Permasalahan sampah sudah mulai dirasakan. Sampah menumpuk dan jarang terangkut hingga tuntas oleh Dinas Kebersihan Kota untuk dibawa ke TPA.

Selain itu karena Kelurahan Kandang Limun juga merupakan lokasi dimana kampus Universitas Bengkulu berdiri, maka sampah kertas juga menjadi permasalahan lain. Kegiatan belajar mahasiswa baik di kampus maupun di tempat kos yang banyak terdapat di kelurahan ini menghasilkan banyak sampah kertas. Usaha-usaha fotokopi dan penjilidan yang banyak berkembang di kelurahan ini juga menghasilkan sampah kertas yang tidak sedikit.

Metode-metode pengenalterapan tekonologi yang dilakukan dalam kegiatan ini adalah penyuluhan serta pengenalan dan penerapan teknologi. Kegiatan penyuluhan meliputi kegiatan membagi pengetahuan tentang pengelolaan sampah rumahtangga dengan Prinsip 5R, pengetahuan dan keterampilan tentang cara mengolah sampah organik rumahtangga menjadi kompos dengan menggunakan Keranjang Takakura, dan pengetahuan dan keterampilan membuat kertas daur ulang. Sedang kegiatan pengenalan dan penerapan teknologi dilakukan dengan mengajak khalayak sasaran terlibat secara langsung dalam kagiatan transfer pengetahuan dan keterampilan melalui metode Belajar sambil Melakukan (Learning by Doing) tentang cara mengolah sampah organik menjadi kompos dengan Keranjang Takakura dan cara mengolah sampah kertas menjadi kertas daur ulang.

Tahap akhir dari kegiatan Pengabdian pada Masyarakat di Kelurahan Kandang Limun ini adalah evaluasi kegiatan pengenalterapan teknologi yang dilakukan dengan cara menganalisis pandangan atau penilaian khalayak sasaran tentang teknologi yang dikenalterapkan dari aspek teknis, ekonomis, lingkungan, sosial dan budaya. Peserta diminta mengisi borang evaluasi yang telah dipersiapkan sebelumnya.

\section{HASIL DAN PEMBAHASAN}

Kegiatan Pengabdian pada Masyarakat ini telah dilaksanakan di Kelurahan Kandang Limun Kecamatan Muara Bangkahulu Kota Bengkulu pada tanggal 16 Juni 2014 yang dihadiri oleh 11 orang ibu rumahtangga yang juga menjadi kader penggerak PKK Kelurahan Kandang Limun. Seluruh peserta berpartisipasi aktif dalam kegiatan. Ketika penyuluhan dilakukan peserta aktif bertanya dan berdiskusi tentang materi yang disampaikan (Gambar 1). Demikian pula pada saat praktek. 

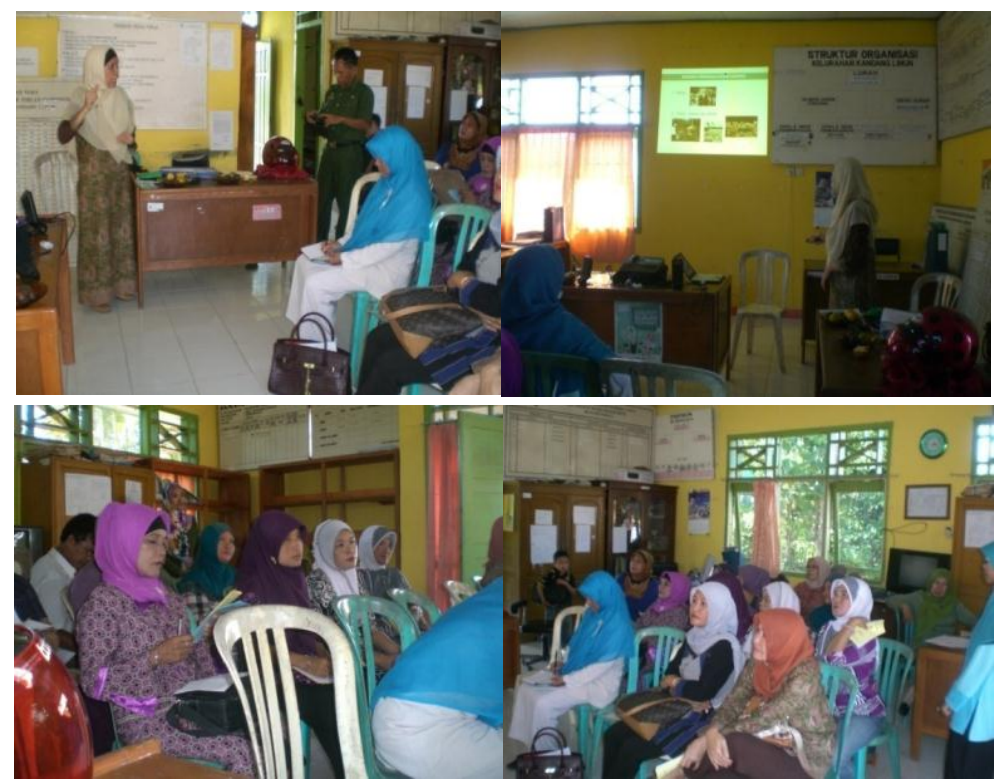

Gambar 1. Kegiatan Penyuluhan

Kegiatan praktek atau belajar sambil melakukan dilakukan sebagai kegiatan lanjutan dari kegiatan penyuluhan. Kegiatan praktek berlangsung dengan lancar, dan peserta antusias melakukan praktek sambil terus bertanya dan berdiskusi. Cara pembuatan dan pemanfaatan Keranjang Ajaib Takakura untuk mengolah sampah organik rumahtangga (Gambar 2).

Kegiatan praktek pengolahan sampah organik rumahtangga didahului dengan persiapan bahan dan alat pembuatan inokulan dan keranjang Takakura. Kemudian dilanjutkan dengan praktek (belajar sambil melakukan) pembuatan inokulan dan keranjang Takakura sampai siap digunakan mengolah sampah organik rumahtangga menjadi kompos.
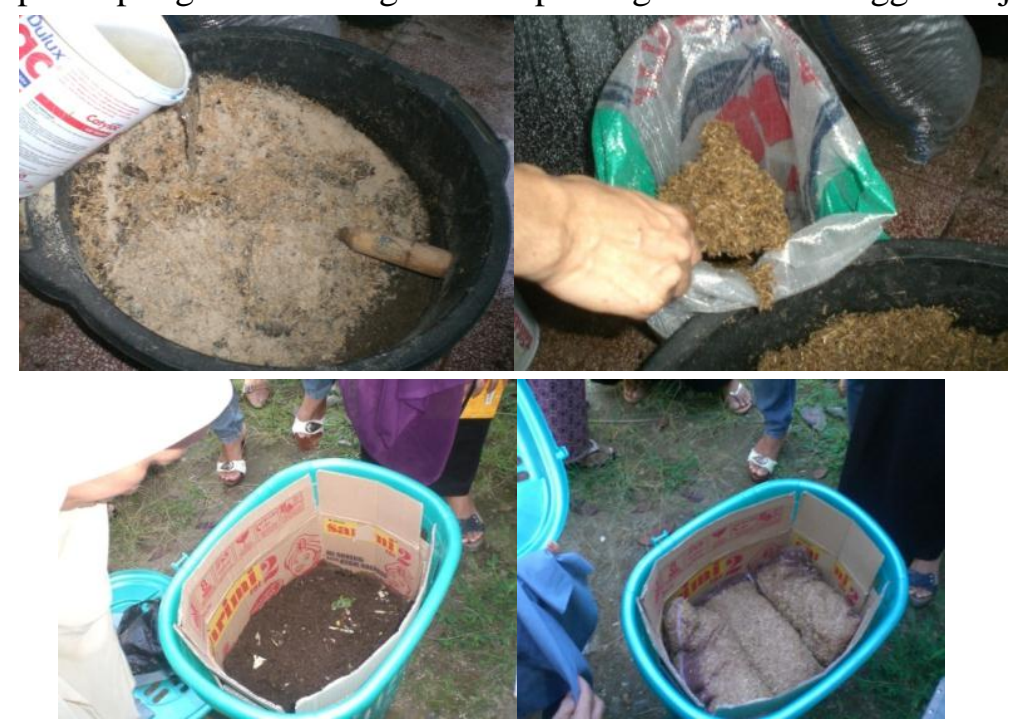

Gambar 2. Praktek Pembuatan Inokulan dan Keranjang Takakura

Selanjutnya dilakukan pula praktek pengolahan sampah kertas menjadi kertas daur ulang (Gambar 3 dan 4). Kegiatan juga diawali dengan mempersiapkan bahan dan alat, 
kemudian dilanjutkan dengan cara atau proses pembuatan kertas daur ulang dengan teknik yang sangat sederhana. Setiap tahapan kegiatan diikuti oleh peserta dengan antusias, mulai dari pembuatan bubur kertas, pewarnaan sampai pencetakan ketas daur ulang.

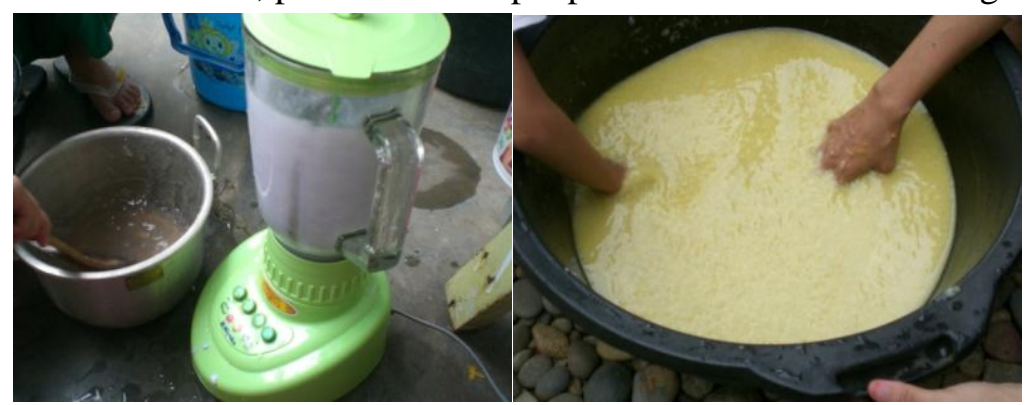

Gambar 3. Pembuatan dan Pewarnaan Bubur Kertas

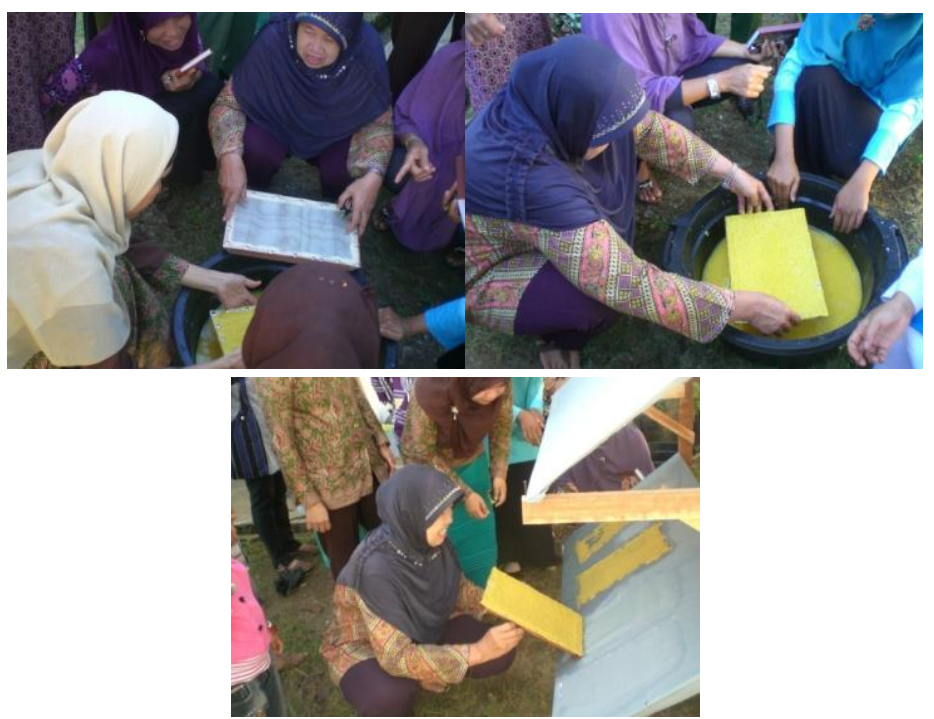

Gambar 4. Pencetakan Kertas Daur Ulang

Hasil evaluasi kegiatan menunjukkan pandangan atau penilaian peserta yang dituangkan dalam borang evaluasi menunjukkan bahwa dari 11 orang peserta kegiatan, tidak ada (0\%) peserta kegiatan menyatakan Tidak Setuju dan atau Sangat Tidak Setuju dengan teknologi yang dikenalterapkan dari segala aspek, baik aspek teknis, ekonomis, lingkungan, sosial dan budaya. Sebagian besar menyatakan Sangat Setuju dan atau Setuju dengan teknologi yang dikenalterapkan. Sebanyak 9 orang dari total peserta yang berjumlah 11 orang $(78,41 \%)$ menyatakan Sangat Setuju dengan teknologi yang dikenalterapkan atau dapat diartikan memberikan pandangan Sangat Baik, sementara sisanya yakni 2 orang $(21,59 \%)$ menyatakan Setuju atau memberikan pandangan Baik terhadap teknologi yang dikenalterapkan.

Empat pernyataan yang paling banyak direspon Sangat Setuju oleh khalayak sasaran adalah:

1. Prinsip 5R dapat dilaksanakan karena alat-alatnya sederhana dan murah $(100,00 \%)$. 
2. Prinsip 5R dapat dilaksanakan karena bahan-bahannya mudah didapatkan dan murah $(90,91 \%)$.

3. Prinsip 5R tidak bertentangan dengan norma sosial atau adat istiadat $(90,91 \%)$.

4. Kompos dan kertas daur ulang yang dihasilkan sangat bermanfaat $(81,82 \%)$.

\section{KESIMPULAN DAN SARAN}

\section{Kesimpulan}

Kegiatan Pengabdian pada Masyarakat yang terdiri dari kegiatan penyuluhan dan praktek tentang pengelolaan sampah rumahtangga dengan prinsip 5R, pengolahan sampah organik menjadi kompos dengan Keranjang Takakura dan membuat kertas daur ulang berjalan lancar.

Hasil evaluasi kegiatan menunjukkan bahwa tidak ada peserta kegiatan yang menyatakan Tidak Setuju atau menilai Tidak Baik terhadap teknologi yang dikenalterapkan. Sebanyak 9 orang (78,41\%) menyatakan Sangat Setuju atau berpandangan Sangat Baik dan sebanyak 2 orang (21,59\%) menyatakan Setuju atau berpandangan Baik.

\section{Saran}

Kegiatan ini dapat dilanjutkan dengan pengenalterapan barang-barang kreasi berbahan kertas daur ulang.

\section{DAFTAR PUSTAKA}

Anonim $^{1}$, 2008, Membuat Keranjang Takakura Sendiri, http://keranjangtakakura. blogspot.com, Diakses Tanggal 16 Maret 2013 Pukul 15.53 WIB.

Anonim $^{2}$, 2011, Keranjang Ajaib Takakura, http://olahsampah.multiply.com, Diakses Tanggal 7 Maret 2013 Pukul 15.20 WIB.

Anonim $^{3}$, 2012, Takakura, Pengelolaan Sampah Gaya Jepang, http://www. radarlampung.co.id, Diakses Tanggal 7 Maret 2013 Pukul 15.00 WIB.

Anonim ${ }^{4}$, 2013, Kotak Takakura Pusdakota, Jakarta, Kami Ingin Perubahan, http://chirpstory.com, DiaksesTanggal 16 Maret 2013 Pukul 16.16 WIB.

Anwar, 2012, Sampah Organik dan Anorganik, http://buletinbelantara.com, Diakses Tanggal 20 Maret 2013 Pukul 16.41 WIB.

Apriadji, Wied Harry, 2000, Memproses Sampah, Penebar Swadaya, Jakarta.

Hidayat, Romdlon, 2012, Bank Sampah: Mendulang Emas dari Sampah, http://csr.pkpu.or.id, Diakses Tanggal 7 Maret 2013 Pukul 15.45 WIB.

http://greenworld-future.blogspot.com, 2011, Pentingnya Daur Ulang, Diakses Tanggal 4 Februari 2014 Pukul 09.10 WIB.

Safitri, Aryanti, 2014, Sampah, http://safitriaryanti.wordpress.com, Diakses Tanggal 12 Maret 2013 Pukul 19.06 WIB. 
Sutidja, Trim, 1999, Daur Ulang Sampah, http://scribd.com, Diakses Tanggal 16 Maret 2013 Pukul 15.00 WIB. 